\title{
AGRICULTURAL EXTENSION AGENTS' EDUCATION AND TURNOVER INTENTIONS IN PUBLIC EXTENSION SERVICES IN ETHIOPIA
}

Mideksa F. Jilito*, Desalegn Y. Wedajo

School of Rural Development and Agricultural Innovation, College of Agriculture and Environmental Sciences, Haramaya University, P.O Box 138, Dire Dawa, Ethiopia.

\section{ART ICLE I N F O}

\section{Article History}

Received: June 17, 2020

Revised: July 28, 2021

Accepted: August 25, 2021

\section{Keywords}

Agricultural extension

Extension agent

Job satisfaction

Turnover intention

Extension education

Perceptions

Public extension services

Ethiopia
A B S T RAC T

Agricultural extension agents provide informal education to equip farmers with new knowledge and skills. They play critical roles for the transfer of agricultural knowledge, technologies, and innovations. However, most of them dissatisfied and intend to find other employment in Ethiopia. Thus, this study was conducted to examine agricultural extension agents' education, perceptions towards job satisfaction, and turnover intention in public agricultural extension services in Ethiopia. The sample frame was the list of all first, second, and third-year mid-career students joined Haramaya University to upgrade their educational qualification. Total 123 extension agents were involved in the study. Primary data were collected using a structured questionnaire and analyzed using descriptive statistics. Results revealed that about $89.40 \%$ of extension agents acquired new knowledge, skills, practices, and attitudinal change during attending their education at Haramaya University. Results also showed that extension agents were dissatisfied with their current job and organization in terms of payment, promotion, benefits, and recognition. Furthermore, survey results indicate that about $68.3 \%$ of extension agents intended to leave their current position and extension organization after completing a Bachelor of Science degree. Therefore, government, private sectors and other stakeholders who work in extension organizations should work on the education and training programs, work motivation, and job satisfaction of agricultural extension agents by designing various incentive packages to increase their work motivation and reduce turnover intentions.

Corresponding Author: Mideksa F. Jilito

Email:mideksafufa@gmail.com

(C) The Author(s) 2021.

\section{INTRODUCTION}

Agricultural extension services in Ethiopia are mainly plied by the government through the ministry of agriculture. Agricultural extension agents are personnel who are responsible for meeting the goals of the extension system (Khalil et al., 2009). They are the key employees of the extension organization who serve as front-line extension professionals involved in multiple activities of agriculture and rural development like transferring agricultural knowledge, technologies and innovations to the farmers (Leta et al., 2018). Extension agents are also responsible for teaching and advising farmers. They provide farmers with essential knowledge, skills and behavioral change that would lead to increased production. Moreover, extension agents provide general advisory services in crop, livestock, and natural resource management at the community level (Tesfaye et al., 2010). Thus, the success of agricultural 
extension work depends on these competencies. Extension agents should possess professional competencies particularly in areas of their job description such as technical and advisory skills, extension research skills, teaching/communication skills, script-writing and audience analysis. Skilful agricultural extension staff is needed for local facilitation, planning and implementation (Hornidge and Ul Hassan, 2010; Maguire, 2012; Hassan, 2013). Therefore, proper training and education of extension agents are critical for Ethiopian agricultural strategies and policy implementation.

The current Ethiopian agricultural extension system is structured from the Ministry of Agriculture to the line regional Bureau of Agricultural Development, then to the zone, district, and the lower administration unit, the kebele. The system uses Farmers' Training Centers (FTCs)-based agricultural extension approach, which is considered to be an entry point for the grass-roots extension services. FTCs assisted by agricultural extension workers. They give agricultural extension services such as farmer training, demonstration of improved farming techniques, market information, and advisory services to farmers in their vicinities. Moreover, Agricultural Technical, Vocational Education and Training (ATVET) College established to produce development agents in different fields of specializations, particularly crop production, animal production, and natural resources management (ATA, 2015).

Agricultural advisory services are under criticism to make significant impacts on the lives of smallholder farmers (Kassa and Alemu, 2016). This pressure is creating new demands for agricultural education, not only in terms of appropriate curricula but also in the mode of instruction. In universities, extension agents trained to upgrade their qualification from diploma or level four to BSc degree level in value chain oriented agricultural extension in nine Ethiopian public universities namely; Haramaya, Hawasa, Bahirdar, Mekelle, Wollo, Jimma, Jigjiga, Samera and Arbaminch Universities. Maguire (2012) explained that ATVET's trainers lack practical field and laboratory experiences, extension skills and knowledge during their study period so they cannot properly train practically oriented courses. As a result, university training focuses on mitigating these quality gaps through full time and/or seasonal on-the-job skill training for extension agents (Davis et al., 2010; Leta et al., 2018). In this way, an increased number of extension agents have opportunities to receive quality extension education to improve their technical and advisory skills that enable them to work directly with rural people. The training seeks to provide practicum, hands-on laboratories, problem-focused courses and field-based enterprises. As part of their training, they returned to their work-place and conducted action research known as Supervised Extension Projects (SEPs) on farmers' farm with the support of their employers. These strengthen the practical experience of agricultural extension professionals to deal with the challenges of agricultural development in their respective districts.

The effectiveness of agricultural extension work highly depends on extension professionals who are qualified, motivated, committed and responsive to the everchanging social, economic and political environment. This means the lion share of extension organization services is handled by frontline extension workers. Thus, motivating agricultural extension agents will achieve sustainable agricultural development and organizational goals (Bolarinwa, 2017). However, most of extension agents intend to find out office level work or other employment after their BSc training. Actual turnover and turnover intention among extension agent is a significant problem for public extension services. Different studies from Ethiopia confirmed that extension agents are often dissatisfied with their salaries, promotion, workload, benefits, recognition, and being stationed in remote rural areas with limited facilities which result in high annual staff turnover (Swanson and Rajalahti, 2010; Gebru et al., 2012; Kelemu et al., 2015). The motivation was found as a core driver of employee behavior in the workplace. Intrinsic motivation in the work-place decreases turnover intention by increasing job satisfaction and decreasing emotional exhaustion (Cho and Lewis, 2011).

Although research work has been done in some parts of Ethiopia by other researchers on factors affecting work motivation and job satisfaction among extension workers, little or nothing has been done on the up grading educational qualification, job satisfaction, and turnover intention among extension agents in Ethiopia. For instance, Golla et al. (2017) conducted on job satisfaction and its determinants among development agents in North Gondar Zone, Amhara Region, Ethiopia. Gebru et al. (2012) worked on challenges of development agents' performance in technology 
dissemination in Southern, Nation, Nationalities and Peoples Regional State, Ethiopia. It has therefore become very pertinent to embark on this research. Therefore, this study aimed to describe socio-economic characteristics of extension agents; to examine agricultural extension agents' education; perceptions towards job satisfaction and turnover intention in public extension services in Ethiopia; and to identify major problems extension agents faced to serve as frontline workers up-on the completion of their B. Sc. degree.

\section{METHODOLOGY}

\section{Description of the study area}

The study area, Haramaya University, was established in 1954 near the town of Haramaya in a small village called Bate. The university is located in Haramaya district, East Hararghe Zone, Oromia Regional State Ethiopia at a distance of $526 \mathrm{~km}$ from the capital city of the country, Addis Ababa. The university is located at a distance of 25 $\mathrm{km}$ from the capital city of the Zone, Harar. The university boasts several recreational facilities and amenities, including a standard stadium, various sports grounds, shopping centers, broadband and wireless internet services, cafeterias and lounges, a kindergarten, a model primary and secondary school, hotels with accommodation services, and other facilities.

\section{Sampling method}

This study was carried out amongst agricultural extension agents who joined Haramaya University to upgrade their educational qualification from diploma or level IV holders to degree level. The sample frame is the list of employees who have been serving as extension agents in various regions of Ethiopia including Oromia, Harari, Gambella, Afar and Dire Dawa regions. These employees are currently enrolled students at Haramaya University to upgrade their educational level from diploma level or level four to Bachelor of Science degree program. The program they attended is known as MidCareer. All batches of mid-career students were selected to participate in the study. In 2019/20 academic year, the total number of first, second and third (final) year students were 48,42 , and 33 , respectively. Thus, a total of $123 \mathrm{mid}$-career students were included in the study as respondents.

\section{Methods of data collection and analysis}

Primary data were collected using structured questionnaires to obtain information from the agricultural extension agents in January 2020. The questionnaires consisted of information about socioeconomic aspects of extension agents, their education, and perceptions towards job satisfaction and turnover intention. The data were quantitative and five-point Likert Scale (strongly disagree to strongly agree) was used for the rating of responses. Secondary data were reviewed from the related published articles, books, proceedings, conferences. Data collected from frontline extension workers through structured questionnaires were processed and coded using SPSS software for further analysis. The data were analyzed using descriptive statistics such as frequency distribution, percentages, means, standard deviations, minimum, and maximum.

\section{RESULTS AND DISCUSSION}

\section{Socio-Economic characteristics of respondents}

The respondents came from various regions of Ethiopia to attend their BSc degree education in agricultural extension. These are Oromia, Harari, Gambella and Afar Regions, and Dire Dawa City Administration. Half of the respondents came from rural areas of the Oromia Region while $17.10 \%$ of them came from rural areas of Dire Dawa City Administration. Currently, they are attending education training at Haramaya University, Ethiopia. The compositions of the respondents include first year (39.10\%), second year (34.10\%) and third (final) year $(26.80 \%)$ students. In terms of gender, $92.70 \%$ of them were male whereas $7.30 \%$ female. This showed that female extension agents are less in working as frontline extension workers, and as upgrading their educational qualification due to indoor workload activities (Table 1). The mean age and working experience of respondents were 29.94 and 8.36 years respectively, while the mean household size and children under age 18 years of the respondents were 3 and 1 persons, respectively. This indicates that majority of the respondents within the age bracket of active work, and served the government in extension organization on average eight years. Furthermore, the results showed that one respondent consumes and cover costs of three persons on an average in one household. However, agricultural staffs in general and extension agents in particular are the most poorly paid members compared to other sector officers. The monthly salary for the extension agent is unattractive. The mean monthly gross salary of respondents was 4107 birr (ETB). The minimum and maximum monthly salary of frontline extension workers 
were 2004 and 7000 birr respectively. Government tax and pension are deducted from the gross salary. The respondents use this salary to cover their social expenses (Table 2).

Table 1. General information of respondents $(\mathrm{N}=123)$.

\begin{tabular}{|c|c|c|c|}
\hline & Characteristics & Frequency & Percent \\
\hline \multirow[t]{3}{*}{ Category of respondents } & First year & 48 & 39.10 \\
\hline & Second year & 42 & 34.10 \\
\hline & Third year & 33 & 26.80 \\
\hline Name of Regional State/City & Oromia Region & 62 & 50.40 \\
\hline \multirow[t]{4}{*}{ Administration } & Dire Dawa City Administration & 21 & 17.10 \\
\hline & Gambella Region & 19 & 15.40 \\
\hline & Harari Region & 15 & 12.20 \\
\hline & Afar Region & 6 & 4.90 \\
\hline \multirow[t]{2}{*}{ Sex } & Male & 114 & 92.70 \\
\hline & Female & 9 & 7.30 \\
\hline \multirow[t]{2}{*}{ Marital status } & Married & 105 & 85.40 \\
\hline & Single & 18 & 14.60 \\
\hline
\end{tabular}

Table 2. Descriptive statistics of continuous variables $(\mathrm{N}=123)$.

\begin{tabular}{lcccc}
\hline Variables & Minimum & Maximum & Mean & Std. Deviation \\
\hline Age (years) & 23 & 45 & 29.94 & 5.39 \\
Household size (number) & 0 & 7 & 3.34 & 1.93 \\
Children living at home under age 18 (number) & 0 & 4 & 1.48 & 1.19 \\
Experience as frontline extension workers (years) & 2 & 25 & 8.36 & 4.59 \\
Monthly salary (ETB) & 2004.00 & 7182.00 & 4107.01 & 1183.98 \\
\hline
\end{tabular}

Position of Frontline Extension Workers Served in Extension Origination

Before joining Haramaya University to pursue BSc education, respondents had served at various positions in district level extension organization. Of the total 123 sample respondents, $118(95.9 \%)$ of them served as frontline extension workers or development agents at kebele level while the remaining 5(4.1\%) never served as DAs, but as Subject Matter Specialists (SMSs) in extension organization (Table 3). Out of $95.9 \%$ extension agents served as frontline extension workers, $58.5 \%$ of them had worked as frontline extension workers whereas $37.4 \%$ of them served as both frontline extension workers and other positions such as supervisor (18.7\%), extension officer (9.8\%), head of the extension office at the district level, and $3.3 \%$ of them served as another position in extension organization at district level.

Table 3. Positions respondents served in extension organization.

\begin{tabular}{lcc}
\hline Position respondents engaged in & Frequency & Percent \\
\hline Served as frontline extension workers (DAs) & 118 & 95.9 \\
Not working as frontline extension workers but as SMSs & 5 & 4.1 \\
Only working as frontline extension workers (DAs) & 72 & 58.5 \\
Working both as frontline extension workers and other position & 46 & 37.4 \\
\hline
\end{tabular}

\section{Agricultural Extension Education for Frontline} Extension Workers in Ethiopia

About $99.2 \%$ of respondents responded that BSc education for frontline extension workers at university is relevant to expand and strengthen their knowledge and skills while $0.8 \%$ of them responded that it is irrelevant.

The results showed that respondents acquired new 
knowledge and skills in the area of extension through attending practical and problem-solving focused courses. Field based courses such as Supervised Extension Projects (SEPs) were also delivered to the trainee from first year to third year. This means they took SEP-I (need assessment), SEPs-II (proposal preparation and presentation), SEPs-III (Project implementation phase at farmers farm), and SEPs-IV (evaluation phase of the field project) at first year second semester, second year first semester, second year second semester and third year first semester, respectively. In terms of acquiring new skills, knowledge and practices at Haramaya University during BSc education, about $96.70,90.20,87.80$ and $85.40 \%$ of respondents obtained skills and knowledge on communicating agricultural information, production and marketing of crops and animals, English language and basic computer, and extension research, respectively (Table 4).

About $89.40 \%$ of the respondents expressed that the competencies such as knowledge, skill, new practices, attitudinal change they acquired during BSc education enabled them to serve as frontline extension worker in the extension organization. They also responded that they were satisfied with the topics/contents covered in the BSc education, which in turn enables them after graduated from Haramaya University to continue as frontline extension workers/DAs.

Table 4. Methods of teaching and competencies acquired by respondents $(\mathrm{N}=123)$.

\begin{tabular}{lccc}
\hline Teaching methods & Response & Frequency & Percent \\
\hline Problem solving focused courses & Yes & 97 & 78.90 \\
& No & 26 & 21.10 \\
\hline Field based research & Yes & 92 & 74.80 \\
& No & 31 & 25.20 \\
\hline Practical based courses & Yes & 70 & 56.90 \\
& No & 53 & 43.10 \\
\hline Laboratories & Yes & 47 & 38.20 \\
& No & 76 & 61.80 \\
\hline Type of competence & & & \\
\hline Agricultural communication skills & Yes & 119 & 96.70 \\
& No & 4 & 3.30 \\
\hline Skill of crop and animal production and marketing & Yes & 111 & 90.20 \\
& No & 12 & 9.80 \\
\hline English language and basic computer skills & Yes & 108 & 87.80 \\
& No & 15 & 12.20 \\
\hline Extension research skills & Yes & 105 & 85.40 \\
& No & 18 & 14.60 \\
\hline Decision making and problem-solving skills & Yes & 93 & 75.60 \\
& No & 30 & 24.40 \\
\hline Soil and water conservation practices and management & Yes & 92 & 74.80 \\
& No & 31 & 25.20 \\
\hline Technical and advisory skills & Yes & 91 & 74.00 \\
& No & 32 & 26.00 \\
\hline Leadership skills & Yes & 73 & 59.30 \\
& No & 50 & 40.70 \\
\hline Entrepreneurial skills & Yes & 68 & 55.30 \\
& No & 55 & 44.70 \\
\hline
\end{tabular}

\section{Perceptions of agricultural extension agents towards job satisfaction}

One of the key problems of public extension services in Ethiopia is the poor incentive and reward system (World Bank and IFPRI, 2010). This is largely caused by the offering only a few/no rewards, poor facilities, and low recognition for extension agents, leading to a general lack of motivation and morale (Swanson and Rajalahti, 2010). The extension agents often lack the job amenities and incentives such as daily allowance, shelter, transportation facility, insurance, or field kits. Davis et al. (2010) remarked that poor incentives are causes of 
low job satisfaction among extension agents in Ethiopia. As a result, many extension agents are hardly able and/or willing to give efficient advisory services in their area of operation. The job satisfaction of extension agents in Ethiopia appears low. Many extension agents seek alternative career opportunities due to low job satisfaction (Swanson and Rajalahti, 2010).

Results revealed that about $78 \%$ of respondents satisfied with their current job whereas $22 \%$ of them dissatisfied. The perception of extension agents towards their current job satisfaction in terms of payment, benefits, and recognition was measured using a 5-point Likert-type scale from strongly disagree to strongly agree based on five items. For instance, $42.30 \%$ of respondents strongly disagree with the statement of fair payment for the work they have done while $14.6 \%$ of them strongly agree. This means, the majority of the respondents responded that payment for their work is unfair compared to work load. Moreover, $34.2 \%$ of respondents strongly disagree with the statement 'there is too little chance for promotion on my job'. This indicates that promotion is not a serious problem in the extension organization.

Based on years of experience or educational qualification, extension workers are promoted to the next career development. Results also showed that 35, 26.8, 21.1, 16.3 and 0.8 percent of respondents agree, strongly agree, strongly disagree, and disagree respectively for the statement 'I am not satisfied with the benefits I receive'. Furthermore, the mean score of respondents' perceptions about the relationship between doing a good job and receiving recognition was 2.58 with a standard deviation of 1.58 , whereas the mean score of their perception towards the sense of pride in doing their job was 3.82 with a standard deviation of 1.48 (Table 5).

Table 5. Respondents' perceptions and feelings towards job satisfaction by percent $(\mathrm{N}=123)$.

\begin{tabular}{lccccccc}
\hline Statements/items & $\begin{array}{c}\text { Strongly } \\
\text { disagree }\end{array}$ & Disagree & Neutral & Agree & $\begin{array}{c}\text { Strongly } \\
\text { agree }\end{array}$ & Mean & SD \\
\hline $\begin{array}{l}\text { I feel I am being paid a fair amount for the } \\
\text { work I do }\end{array}$ & 42.3 & 30.1 & 2.4 & 10.6 & 14.6 & 2.25 & 1.46 \\
$\begin{array}{l}\text { There is too little chance for promotion on } \\
\text { my job }\end{array}$ & 34.2 & 28.5 & 1.6 & 20.3 & 15.4 & 2.54 & 1.51 \\
I am not satisfied with the benefits I receive & 21.1 & 16.3 & 0.8 & 35.0 & 26.8 & 3.30 & 1.54 \\
When I do a good job, I received the & 35.8 & 26.8 & 0.8 & 16.3 & 20.3 & 2.58 & 1.58 \\
$\begin{array}{l}\text { recognition } \\
\text { I feel a sense of pride in doing my job }\end{array}$ & 13.8 & 12.2 & 0.8 & 24.4 & 48.8 & 3.82 & 1.48 \\
\hline
\end{tabular}

\section{Perceptions of agricultural extension agents towards turnover intention}

Previous research in extension showed positive relationships between employees' turnover intention and heavy workload, occupational stress, work-life balance, low salary, long work hours, lack of recognition, and high requirements for advancement (Safrit and Owen, 2010; Young et al., 2013; Harder et al., 2015). Low job satisfaction increases extension employee turnover and turnover intention (Martin and Kaufman, 2013). Actual turnover and turnover intention among extension agent is a significant problem for extension services.

Survey results showed that about $68.3 \%$ of frontline extension workers intended to leave their current position and organization after completed BSc degree while the remaining $31.7 \%$ desired to continue as frontline extension workers in the same organization.
Out of $68.3 \%$ of respondents intended to leave their current position within public agricultural extension services, about $43.1,41.5$ and $36.6 \%$ desired to work as extension officer experts at district, regional and zonal levels, respectively.

Furthermore, some of them need to be assigned as a new managerial or political position in the same organization. For example, 35\% of them intended to work as coordinator to supervise frontline extension workers whereas $27.6 \%$ of them want to serve as head or vice head of Agricultural Office at district level. Finally, few of them intended to transfer to other sectors outside agriculture in the same district (e.g cooperatives office, irrigation development office, etc). Some of the respondents also intended to search for another organization paying higher salary and provide benefits outside public agricultural extension services. For 
instance, about 42.6, 27.6, 16.4 and $13.4 \%$ of respondents intended to join research centers, nongovernmental organization, agricultural colleges and universities, and agriculture based private sectors, respectively.

Regarding respondents' perceptions towards turnover intention, about $42.3 \%$ of them strongly agree with the statement of actively look for a new job up-on the completion of BSc degree while $22 \%$ of them agree. This means that $64.3 \%$ of them intended to leave the extension organization. The remaining 15.4, 13 and $7.3 \%$ strongly disagree, disagree and neutral to the statement, respectively. In addition to this, $38.2 \%$ of respondents agreed that they often think about leaving the organization while 28.5 of them strongly agree with the statement, so that $66.7 \%$ of them already planned to leave the extension organization. The remaining $19.5,11.4$, and $2.4 \%$ of respondents disagree, strongly disagree, and neutral with statement, respectively (Table 6).

Table 6. Perceptions of extension agents towards their services as DAs and turnover intention after B.Sc. degree.

\begin{tabular}{|c|c|c|c|c|c|c|c|c|c|c|c|c|}
\hline \multirow[t]{2}{*}{ Statement/items } & \multicolumn{2}{|c|}{$\begin{array}{c}\text { Strongly } \\
\text { disagree (1) }\end{array}$} & \multicolumn{2}{|c|}{$\begin{array}{c}\text { Disagree } \\
\text { (2) }\end{array}$} & \multicolumn{2}{|c|}{ Neutral (3) } & \multicolumn{2}{|c|}{ Agree (4) } & \multicolumn{2}{|c|}{$\begin{array}{c}\text { Strongly } \\
\text { agree (5) }\end{array}$} & \multirow[t]{2}{*}{ Mean } & \multirow[t]{2}{*}{ SD } \\
\hline & No. & $\%$ & No. & $\%$ & No. & $\%$ & No. & $\%$ & No. & $\%$ & & \\
\hline $\begin{array}{l}\text { Completing BSc degree } \\
\text { helps me to work in the } \\
\text { office }\end{array}$ & 5 & 4.1 & 12 & 9.8 & 5 & 4.1 & 40 & 32.5 & 61 & 49.5 & 4.14 & 1.13 \\
\hline $\begin{array}{l}\text { Completing BSc degree } \\
\text { equipped me with } \\
\text { knowledge and skills }\end{array}$ & 6 & 4.9 & 8 & 6.5 & 2 & 1.6 & 48 & 39.0 & 59 & 48.0 & 4.19 & 1.08 \\
\hline $\begin{array}{l}\text { Extension organization } \\
\text { should provide } \\
\text { incentives for } \\
\text { extension agents to } \\
\text { attract employees at } \\
\text { fieldwork }\end{array}$ & 11 & 8.9 & 14 & 11.4 & 20 & 16.3 & 52 & 42.3 & 26 & 21.1 & 3.55 & 1.20 \\
\hline $\begin{array}{l}\text { I am willing and } \\
\text { motivated to work as } \\
\text { extension agents at } \\
\text { kebele level }\end{array}$ & 47 & 38.2 & 34 & 27.6 & 5 & 4.1 & 21 & 17.1 & 16 & 13.0 & 2.39 & 1.46 \\
\hline $\begin{array}{l}\text { I would like to work as } \\
\text { an extension officer at } \\
\text { district level after BSc } \\
\text { degree }\end{array}$ & 10 & 8.0 & 13 & 10.6 & 20 & 16.3 & 52 & 42.3 & 28 & 22.8 & 3.61 & 1.18 \\
\hline $\begin{array}{l}\text { I will actively look for a } \\
\text { new job on the } \\
\text { completion of BSc } \\
\text { degree }\end{array}$ & 19 & 15.4 & 16 & 13.0 & 9 & 7.3 & 27 & 22.0 & 52 & 42.3 & 3.63 & 1.51 \\
\hline $\begin{array}{l}\text { I often think about } \\
\text { leaving the } \\
\text { organization }\end{array}$ & 14 & 11.4 & 24 & 19.5 & 3 & 2.4 & 47 & 38.2 & 35 & 28.5 & 3.53 & 1.38 \\
\hline $\begin{array}{l}\text { I will probably look for } \\
\text { a new job in the next } \\
\text { year }\end{array}$ & 10 & 8.0 & 20 & 16.3 & 6 & 4.9 & 37 & 30.1 & 50 & 40.7 & 3.79 & 1.34 \\
\hline $\begin{array}{l}\text { The organization I am } \\
\text { working for is not } \\
\text { attracting employees }\end{array}$ & 25 & 20.3 & 10 & 8.1 & 5 & 4.1 & 36 & 29.3 & 47 & 38.2 & 3.57 & 1.55 \\
\hline $\begin{array}{l}\text { My current working } \\
\text { environment is not } \\
\text { conducive }\end{array}$ & 15 & 12.2 & 23 & 18.7 & 4 & 3.3 & 49 & 39.8 & 32 & 26.0 & 3.49 & 1.38 \\
\hline
\end{tabular}


Problems hindering work motivation of frontline extension workers

Frontline extension workers faced various problems while rendering extension services to the farmers. Most of extension agents are working under difficult and disadvantageous conditions characterized by lack of infrastructural facilities such as transportation problem, residential problem, remoteness, and health problems due to lack of health services in the rural area (Gebru et al., 2012; Asayehegn et al., 2012). For instance, 30 (24.4\%) of respondents faced transportation problems. About $22.8 \%$ of them mentioned lack of house and office at the workplace as one of the problems. Furthermore, the following problems were ranked by the respondents.

Table 7. Major problems influencing respondents' motivation to work at kebele level.

\begin{tabular}{lccc}
\hline Problems & Frequency & Percent & Rank \\
\hline Lack of transportation facilities for extension agents e.g motor-cycle & 30 & 24.4 & 1 \\
Lack of house and office for extension agents in their assigned kebeles & 28 & 22.8 & 2 \\
Lack of training materials such as stationeries, audiovisuals, manuals & 18 & 14.6 & 3 \\
Workload on extension agents & 14 & 11.4 & 4 \\
Insufficient short term and long-term training to carryout duties properly & 8 & 6.5 & 5 \\
Lack of ICT such as internet and other social media & 7 & 5.7 & 6 \\
Inadequate public funding for agricultural extension services & 6 & 4.9 & 7 \\
Lack of communication between district agricultural office and extension & 5 & 4.0 & 8 \\
agents & & & \\
Extension agents forced by supervisors to do nonprofessional activities & 4 & 3.3 & 9 \\
Lack of transparency in the organization & 3 & 2.4 & 10 \\
\hline
\end{tabular}

\section{CONCLUSION AND RECOMMENDATIONS}

Results revealed that some of frontline agricultural extension workers were partly dissatisfied with their current job position and organization. Although agricultural extension agents are key employees of the extension organization who serve as front-line extension professionals, their work motivation and job satisfaction were influenced by various variables such as low salary, irregular promotion, unattractive work environment, no/little benefits, incentives, recognition and appreciation. Therefore, the Ethiopian government, private sectors and other stakeholders should work on the work motivation and job satisfaction of agricultural extension agents through providing different incentive packages, creating a favorable working environment, transportation facilities and field kits, to reduce turnover intention thereby improve extension services.

All government and non-government stakeholders working on agricultural extension across the Ethiopia should give a brief attention to on-the-job training for development agents in order to improve their level of knowledge, skill and attitude. Moreover, district, zonal and regional Agricultural and Rural Development offices/bureau should ensure regular promotions, handsome incentives and reduction of the workload of extension agents.

\section{ACKNOWLEDGEMENTS}

The authors would like to thank college of Agriculture and Environmental Sciences, Haramaya University, Ethiopia for duplicating the questionnaires. The authors would also like to thanks all development agents participated in the study.

\section{REFERENCES}

Asayehegn, K., G. Weldegebrial and D. Kaske. 2012. Effectiveness of development agents performances in agricultural technology dissemination: The case of Southern Nations Nationalities and Peoples Regional State (SNNPRS), Ethiopia. Journal of Agricultural Extension and Rural Development, 4: 446-55.

ATA. 2015. Seed system development strategy: Vision, systemic challenges, and prioritized interventions. Ethiopian Agricultural Transformation Agency (ATA): Working strategy document, Addis Ababa, Ethiopia. Place Published.

Cho, Y. J. and G. B. Lewis. 2011. Turnover Intention and Turnover Behavior. Review of Public Personnel Administration, 32: 4-23.

Davis, K., B. Swanson, D. Amudavi, D. A. Mekonnen, A. Flohrs, J. Riese and E. Zerfu. 2010. In-depth assessment of the public agricultural extension 
system of Ethiopia and recommendations for improvement. International Food Policy Research Institute (IFPRI) Discussion Paper, 1041.

Gebru, G. W., K. Asayehegn and D. Kaske. 2012. Challenges of development agents (DAs) performance in technology dissemination: A case from Southern, Nation, Nationalities and Peoples Regional State (SNNPRS), Ethiopia. Scholarly Journal of agricultural science, 2: 208-16.

Golla, S. Y., G. A. Birhanu and A. D. Shishigu. 2017. Job Satisfaction and its Determinants among Development Agents in North Gondar Zone, Amhara Region, Ethiopia. Research Journal of Social Science and Management, 6: 1-7.

Harder, A., J. Gouldthorpe and J. Goodwin. 2015. Exploring organizational factors related to Extension employee burnout. Journal of Extension, 53: 2FEA2.

Hassan, M. M. U. 2013. Nurturing Interdisciplinarity in Agricultural Research through Capacity-Building: A case study of ZEF's Uzbekistan Project, Bonn University

Hornidge, A.-K. and M. Ul Hassan. 2010. From'plausible promises' to transdisciplinary innovation research in Uzbekistan: process outline and lessons learnt. Rural Development News: 1-11.

Kassa, B. and D. Alemu. 2016. Agricultural research and extension linkages: Challenges and intervention options. Ethiopian Journal of Agricultural Sciences, 27: 55-76.

Kelemu, K., M. Sime, M. Hailu and T. Zalalam. 2015. Determinants and Levels of Agricultural
Development Agents Job Satisfaction: The Case of Kalu Woreda, South Wollo Zone of the Amhara National Regional State. Ethiopian Journal of Business and Economics (The), 4: 149.

Khalil, A. H. O., M. Ismail, T. Suandi and A. D. Silong. 2009. Human resource development competencies as predictors of agricultural extension agents' performance in Yemen. Human Resource Development International, 12: 429-47.

Leta, G., G. Kelboro, T. Stellmacher, K. Van Assche and A.K. Hornidge. 2018. Nikinake: the mobilization of labour and skill development in rural Ethiopia. Natural Resources Forum, 42: 93-107.

Maguire, C. J. 2012. Agricultural Education and Training to Support Agricultural Innovation Systems. The World Bank. Place Published. pp.107-77.

Safrit, R. D. and M. B. Owen. 2010. A conceptual model for retaining county Extension program professionals. Journal of Extension, 48: 1-10.

Swanson, B. E. and R. Rajalahti. 2010. Strengthening agricultural extension and advisory systems. Agriculture and Rural Development Discussion Paper, No. 45. World Bank, Washington DC.

Tesfaye, T., R. S. Karippai and T. Tesfaye. 2010. Effectiveness of training offered by the Ethiopian Institute of Agricultural Research to farmers: The case of Holetta, Melkassa and Debre Zeit Agricultural Research Centres. African Journal of Agricultural Research, 5: 500-13.

Young, J. A., J. Stone, O. Aliaga and B. Shuck. 2013. Job embeddedness theory : can it help explain employee retention? Journal of Extension, 51: 1-7.

Publisher's note: EScience Press remains neutral with regard to jurisdictional claims in published maps and institutional affiliations.

Open Access This article is licensed under a Creative Commons Attribution 4.0 International License, which permits use, sharing, adaptation, distribution and reproduction in any medium or format, as long as you give appropriate credit to the original author(s) and the source, provide a link to the Creative Commons license and indicate if changes were made. The images or other third-party material in this article are included in the article's Creative Commons license, unless indicated otherwise in a credit line to the material. If material is not included in the article's Creative Commons license and your intended use is not permitted by statutory regulation or exceeds the permitted use, you will need to obtain permission directly from the copyright holder. To view a copy of this license, visit http://creativecommons.org/licenses/by/4.0/. 